\title{
Review \\ Renewable Energy Development in the Gulf Cooperation Council Countries: Status, Barriers, and Policy Options
}

\author{
Aisha Al-Sarihi ${ }^{1, *}$ and Noura Mansouri ${ }^{2}$ \\ 1 Middle East Institute, National University of Singapore, 29 Heng Mui Keng Terrace, Block B \#06-06, \\ Singapore 119620, Singapore \\ 2 King Abdullah Petroleum Studies and Research Center, Riyadh 11672, Saudi Arabia; \\ noura.mansouri@kapsarc.org \\ * Correspondence: meiasa@nus.edu.sg
}

check for updates

Citation: Al-Sarihi, A.; Mansouri, N. Renewable Energy Development in the Gulf Cooperation Council

Countries: Status, Barriers, and Policy Options. Energies 2022, 15, 1923. https://doi.org/10.3390/ en15051923

Academic Editor: Abdelali El Aroudi

Received: 1 February 2022

Accepted: 1 March 2022

Published: 6 March 2022

Publisher's Note: MDPI stays neutral with regard to jurisdictional claims in published maps and institutional affiliations.

Copyright: (c) 2022 by the authors. Licensee MDPI, Basel, Switzerland. This article is an open access article distributed under the terms and conditions of the Creative Commons Attribution (CC BY) license (https:// creativecommons.org/licenses/by/ $4.0 /)$.

\begin{abstract}
The countries of the Gulf Cooperation Council (GCC)—Bahrain, Kuwait, Oman, Qatar, Saudi Arabia, and the United Arab Emirates-hold almost 30\% of the world's total proven oil reserves and around $20 \%$ of its total proven natural gas reserves. They are also endowed with a high abundance of renewable energy resources such as solar and wind. Yet, the GCC's primary energy consumption is still dominated by fossil fuels, and the share of renewable energy still does not exceed $1 \%$. Drawing on secondary data, including journal articles, governmental and companies' websites, and reports and newspaper articles, this paper assesses the reasons behind their underutilization of renewable energy resources. Whereas technical and economic feasibility issues had been identified as the main barriers to slow the uptake of renewable energy technologies in the GCC, this paper uncovered that various additional factors have remarkably influenced such delays. High hydrocarbon subsidies, low electricity tariff structure, fragmented energy policy, the absence of dedicated renewable energy regulator and regulatory framework, and a highly controlled power market are major barriers to renewable energy adoption in the GCC. The paper concludes with policy options to inform scaling up the adoption of renewable energy in the GCC.
\end{abstract}

Keywords: renewable energy; Gulf Cooperation Council (GCC); barriers; policies

\section{Introduction}

Global warming — caused by anthropogenic greenhouse gas (GHG) emissions sourced from the combustion of hydrocarbons (coal, oil, and gas) [1,2] -along with increasing energy demands globally, are among the main triggers in the global search for alternative sources of energy that are less polluting and cleaner, like renewable energy technologies.

Hydrocarbon resources-with almost $30 \%$ of the world's total proven oil reserves and around $20 \%$ of its total proven natural gas reserves [3] - have been central in meeting the energy needs of the Gulf Cooperation Council (GCC) countries-Bahrain, Kuwait, Oman, Qatar, Saudi Arabia, and the United Arab Emirates. However, the changing dynamics of the energy market both domestically and internationally has created pressure as well as a window of opportunity for the GCC states to re-assess their renewable energy development. The GCC states are faced with many internal challenges that trigger the need to develop alternative energy sources. These include growing domestic energy consumption, eating up oil and gas export potential, and triggering the energy security profile across the region. Further, annual rise of GHG emissions [4] and increases in air pollutants due to industrial expansion and heavy reliance on hydrocarbon resources for operation are other factors that trigger the search for alternative clean energy sources. Furthermore, global climate mitigation measures targeting reduced consumption of hydrocarbons impose risk to the economic stability of oil-exporting GCC states. Renewable energy technologies represent an opportunity for GCC states to tackle such challenges and, at the same time, support their ambitions to diversify economies away from high dependence on hydrocarbons. 
Renewable energy potential, particularly solar, seems to be remarkable and more so given the geographic location of the Arabian Peninsula within the sunbelt. While the GCC states are home to abundant renewable resources [5-7], hydrocarbons continue to meet most of the Gulf Arab states' primary energy needs, accounting for nearly 99\% of primary energy consumption in the region [8], and the current role of renewables in meeting the region's growing energy demand remains relatively negligible. Aware of the changing energy dynamics, the GCC investments in renewable energy have been on the rise, albeit slowly. That is, the total renewable energy installed capacity has increased from 17 megawatts in 2011 to 3271 megawatts in 2020 [9]. Yet, the current share of renewable energy in the region's total primary energy consumption still does not exceed 1\%. Against this background, this paper aims to assess the reasons behind such underutilization of renewable energy resources in the GCC states.

Growing attention has been given to assess the barriers that have affected the growth of renewable energy development in the GCC (see, for example, [10-18]). The latest investigation found that while institutions are conducive to promoting the development of renewables readily available in some GCC countries, they lack a clear mandate and dedicated planning capacity with limited incentives, regulations, and enforcement environment to attract investors [7,11]. Furthermore, market distortions, especially subsidized fuel and electricity, have led to low energy prices in the region and were identified as a major challenge that has discouraged the competitiveness of renewables compared to conventional energy sources $[14,16]$. A recent study identified the design and implementation of financial policies to support renewable energy adoption, which has been a challenge for their large-scale adoption $[19,20]$. These investigations provide a good explanation of why the share of renewable energy in the GCC has remained low. Yet, a systematic identification of barriers that explain the reasons behind the adoption of renewable energy in the GCC has been missing, or where available, is outdated. This paper contributes by providing an updated discussion of renewable energy adoption barriers in the GCC. The paper also provides a systematic identification of different technological, economic, institutional, cultural, and R\&D barriers by discussing the general and specific barriers that have contributed to each barrier category.

This paper draws on secondary data sources, including scientific journal articles, governmental and companies' websites and reports, and newspaper articles. The specific objectives of this paper are to: justify the importance of advancing renewable energy in the GCC (Section 2); provide an overview of the current state of renewable energy development in each GCC state (Section 3); identify the barriers that have slowed the deployment of renewable energy technologies across the GCC (Section 4); and put forward policy recommendations to overcome barriers and promote successful implementation of renewable energy in the GCC (Section 5).

\section{Why Scale up the Deployment of Renewable Energy Technologies}

Renewable energy presents an opportunity for the GCC states to address the emerging challenges of energy security, rising greenhouse gas emissions, air quality, and the adverse impacts of climate change.

\subsection{Renewable Energy Technologies Boost Economic Diversification and Create Jobs}

The GCC economies depend heavily on oil and gas export revenues, with a narrow export profile dominated by oil and gas: accounting for 53\% of total exports in Bahrain, 91\% in Kuwait, 75\% in Oman, 94\% in Qatar, 77\% in Saudi Arabia, and 74\% in the UAE in 2018 [21]. Oil and gas export revenues have been contributing significantly to the GCC's total governmental revenues, accounting for $82.4 \%$ of Bahrain's total revenues in $2018 ; 89.6 \%$ in Kuwait, 78.2\% in Oman, 83.3\% in Qatar, 67.5\% in Saudi Arabia, and 36.1\% in the UAE. They also accounted for 42.1\% of Kuwait's Gross Domestic Product (GDP) in 2019, 24.2\% in Saudi Arabia, 24.9\% in Oman, 16.9\% in Qatar and 16.2\% in the UAE [22]. This heavy economic reliance on hydrocarbon export revenues and the region's high vulnerability 
to oil prices have triggered the GCC states to pursue ambitious economic diversification plans and expand their product base away from hydrocarbons. Most of the GCC economic diversification plans intend to increase the participation of the private sector, create jobs, human capacity building, and expand trade, business services, logistics, tourism, and manufacturing. We argue that expanding investments in renewables could support the GCC countries in their efforts to diversify their economies and create jobs by encouraging investments and involvement of small and medium enterprises along the value chain [23].

Some studies suggest that government spending on renewables creates five more jobs per million dollars invested than spending on hydrocarbons [24] and can create four times the additional jobs by 2050 compared to their current level [23]. For the Gulf Arab states, one study suggests that supporting a $100 \%$ transition to renewable energy could unlock many social, economic, and environmental benefits in the long term, including job creation, improved energy security, reduction of air pollution, and health cost savings. Examples include creating around 50,000-500,000 jobs, improving energy security by reducing energy demand by up to $60 \%$, reducing air pollution, and maintaining health cost savings of $1-3 \%$ of GDP by 2050 [25].

\subsection{Renewable Energy Technologies Bring Environmental Co-Benefits}

Renewable energy technologies could play an important role in addressing two environmental issues in the GCC: carbon emissions and air pollution. While not a major contributor to global total greenhouse gas (GHG) emissions (nearly $2.5 \%$ of total global emissions in 2018), climate-related emissions are increasing in the Arab Gulf States by 6\% annually on average [4]. In fact, the Arab Gulf States are by far the world's biggest emitters of climate-changing greenhouse gas emissions (GHG) on a per capita basis. That is because almost all energy needs, for example, water, electricity, industries, and transport, are almost entirely met by oil and gas and because the region has experienced a 5\% surge in energy demand per year. Additionally, a 2019 World Air Quality Index found that three Gulf countries, Bahrain, Kuwait, and the UAE, ranked in the top 10 list of most air polluted countries in the world, exceeding the World Health Organization's annual exposure guideline for fine particulate matter [26]. These results are highly concerning from a climate perspective and public health point of view, highlighting the need to develop alternative energy resources to reduce these emissions [27].

\subsection{Renewable Energy Technologies Enhance National Energy Security}

Despite being home to nearly one-third of the world's oil, and more than one-fifth of global gas reserves-most of which are concentrated between Saudi Arabia, the UAE, Kuwait, and Qatar-the GCC countries are also faced with a looming challenge of energy security.

The GCC states' economic growth and industrial expansion, together with rapidly rising living standards, have increased the regional energy consumption by nearly six times since the 1980s - faster than in any other part of the world [14,28]. For instance, Gulf countries' electricity consumption has exceeded the world average (3 MWh per capita) but also exceeded the level of some major industrial countries, such as the UK (4.9 MWh per capita), and that of other developing countries such as India (1.0 MWh per capita) and China (4.9 MWh per capita). In 2018, the per capita electricity consumption exceeded $10 \mathrm{MWh}$ per capita in five GCCs (Bahrain with 18.6 MWh per capita, Kuwait with 15.4 MWh per capita, Qatar with 16.6 MWh per capita, Saudi Arabia with 10.2 MWh per capita, and the UAE 13.2 MWh per capita). While Oman showed lower levels of energy consumption compared to its neighbors, it still exceeded the world's average, accounting for 7.1 MWh per capita [29].

The increasing domestic consumption of oil and gas resources has led some Gulf countries like Oman, UAE, and Kuwait to import natural gas in order to meet the growing domestic demands. In 2014, natural gas imports in the UAE accounted for $19.2 \%$ of natural gas consumption, $37.7 \%$ in Kuwait, and 10.8\% in Oman [30]. Deploying renewable energy 
technologies in the GCC will not only help in meeting the increasing domestic needs of energy but will help to free up fuel needed for downstream economic diversification projects while also increasing exports.

\subsection{Renewable Energy Technologies Mitigate Economic Losses Associated with Climate Change}

For oil-producing countries, climate change imposes risks to both oil- and non-oilbased economic sectors. Regarding non-oil economic sectors, such as agriculture, food security, water, fisheries, tourism, and infrastructure, the rise in temperatures, falling annual rainfall, sea-level rise, and increased exposure to extreme events (e.g., intense rainfall) have already proved to negatively impact these sectors. A 2018 study suggested that the impact of $3{ }^{\circ} \mathrm{C}$ of warming could cause the GCC large GDP losses of $0.2-0.5 \%$ yearly decline after 2027 and 1.5-3\% yearly decline from 2067 [31]. GDP losses stem from sea-level rise, loss in work productivity due to heat/humidity exposure, and proliferation of infectious disease. Oil-based economic sectors, which are already vulnerable to oil price shocks, can also be vulnerable to the outcomes of global climate change mitigation measures aiming to keep climate change at a (relatively) safe level. Global action to cut greenhouse gas (GHG) emissions through policies aiming to reduce hydrocarbon consumption could impose direct economic losses resulting from reduced demand of oil and gas prices and thus a decline in oil export revenues [32,33]. Against this backdrop, investing in renewables will help the Gulf Arab states in contributing to reducing global GHG emissions and hence reducing the economic risks associated with climate change [28].

\section{The Current State of Renewable Energy in the Six GCC States}

In their long-term economic development visions of the twenty-first century, the GCC countries set out ambitious targets and objectives for diversifying economies, making environmental sustainability an integral part of their economic development visions, including in areas of air quality, sanitation, drinking water, waste management, biodiversity, fisheries, climate change, and pollution. For instance, Saudi Arabia's Vision 2030 holds sustainability at its heart and "drives collective commitment to creatively and responsibly meet current and future energy and climate challenges"; Bahrain Economic Vision 2030 states that "economic growth must never come at the expense of the environment and the long-term well-being of our people"; Kuwait Vision 2035 promises to "ensure environment regulations and efficient sustainability within the state"; Qatar National Vision 2030 states that "economic development and protection of the environment are two demands neither of which should be sacrificed for the sake of the other"; and Oman's Tanfeedh program, promises to advance three environment-related national goals: environmental protection; crisis risk management; and science, technology, and innovation [34]. Importantly, with the exception of Oman and Kuwait, the GCC countries have framed their Nationally Determined Contributions (NDCs) to be in line with their economic diversification efforts [35].

Furthermore, the Gulf states have shown a progressive interest in developing emission reduction initiatives, which in many cases are backed by renewable energy targets. Saudi Arabia, for instance, sat a target for avoiding the use of up to 278 million tons of $\mathrm{CO}_{2} \mathrm{eq}$ annually by 2030 [36], and Oman, in its second NDC, pledged to reduce its greenhouse gas (GHG) emissions by 7\% relative to a business-as-usual scenario by 2030 [37]. To fulfill these aspirations, renewable energy has been an integral part of emissions reduction initiatives. The Gulf Arab states have set renewable energy targets for 2025 and 2030, as well as aspirational long-term objectives for 2050 (Table 1).

To achieve renewable energy targets, the Gulf states have developed a handful of renewable energy initiatives and projects. At the end of 2020, the region had $146 \mathrm{GW}$ of installed power capacity, of which renewable energy accounted for $3271 \mathrm{MW}$. Of that, solar PV technologies remain the most dominant technology (71\%), followed by solar CSP (23\%), biomass and waste ( $4 \%)$, and wind $(2 \%)$. The UAE can be considered a regional leader in renewable energy adoption, accounting for $68 \%$ of total regional renewable energy installed capacity, followed by Saudi Arabia (16\%) and Kuwait (9\%) (Figure 1). Installed renewable 
electricity capacity in the GCC is dominated by a handful of utility-scale solar projects. The currently existing CSP capacity is located in Abu Dhabi's Shams Solar Power Station, Kuwait's Shagaya project, and Saudi Arabia's Waad Al-Shamal. Almost all of the GCC's commercial waste-to-energy generation capacity is in Qatar.

Table 1. GCC renewable energy total installed capacity, targets, and share in the energy mix.

\begin{tabular}{cccc}
\hline Country & $\begin{array}{c}\text { Current Total Installed } \\
\text { Capacity (MW) } \\
\text { (as of 2020) }\end{array}$ & $\begin{array}{c}\text { Share of Renewables } \\
\text { in the Energy Mix } \\
\text { (as of 2020) [9] }\end{array}$ & Renewable Energy Target \\
Bahrain & 10 & $0.1 \%$ & $\begin{array}{c}5 \% \text { of energy mix by 2025; } \\
0.7 \text { GW by 2030; } \\
10 \% \text { by 2035 }\end{array}$ \\
\hline Kuwait & 106 & $0.5 \%$ & $15 \%$ of energy mix by 2030 \\
\hline Oman & 159 & $1.3 \%$ & $\begin{array}{c}10 \% \text { of energy mix by 2025; } \\
30 \% \text { of power demand } \\
\text { by 2030 }\end{array}$ \\
\hline Qatar & 43 & $0.3 \%$ & $20 \%$ of energy mix by 2030 \\
\hline Saudi Arabia & 413 & $0.5 \%$ & $\begin{array}{c}50 \% \text { of electricity } \\
\text { generation } 2030\end{array}$ \\
\hline UAE & 2540 & $7.2 \%$ & $\begin{array}{c}2050: 50 \% \text { clean energy } \\
(44 \% \text { renewables and } \\
6 \% \text { nuclear })\end{array}$ \\
\hline
\end{tabular}

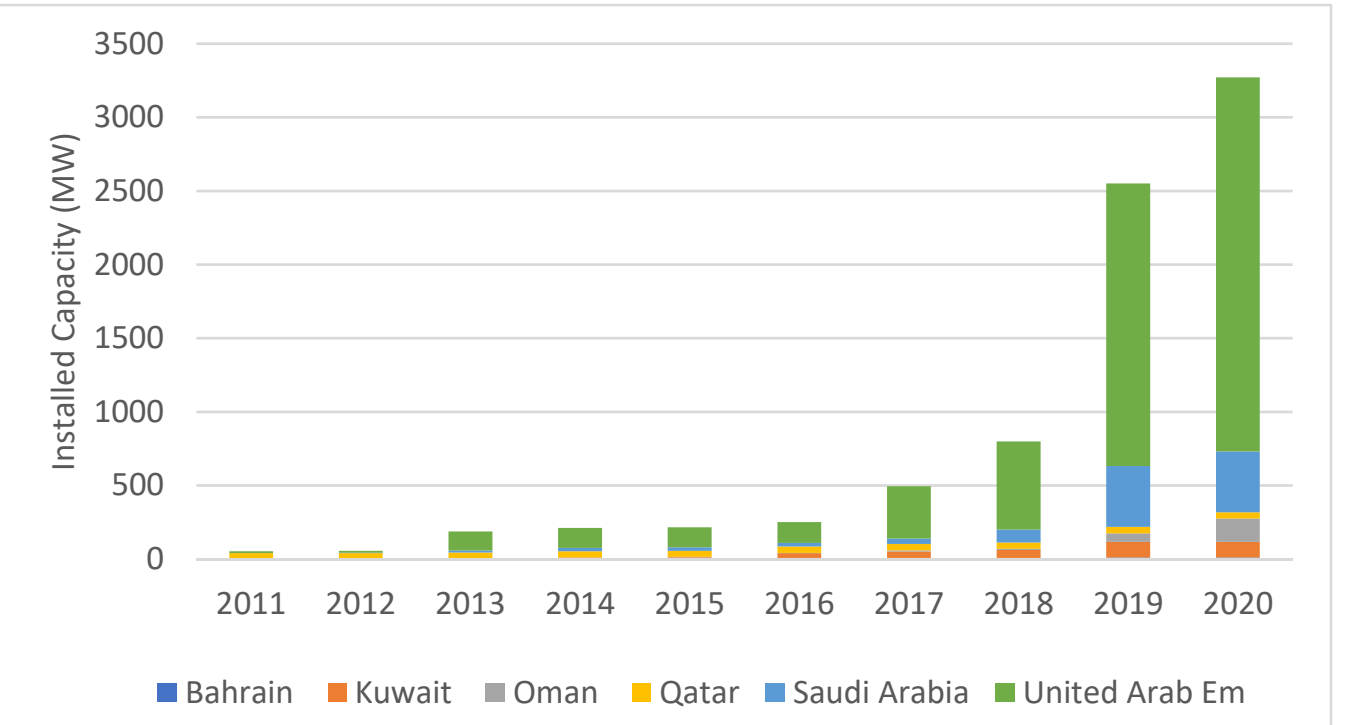

Figure 1. Renewable energy installed capacity in the GCC countries, 2011-2021 [9].

\subsection{Bahrain: Ambitious but Stagnant Developer}

Bahrain launched the kingdom's Economic Vision 2030 in 2008, aimed to reduce dependence on oil and transition towards sustainability. The vision addresses Sustainable Development Goals 2030, with a target of 700 MW of renewable energy generation capacity by 2030 [38]. It also includes a renewable energy target of generating $5 \%$ of its energy from renewables by 2025 and $10 \%$ by 2035. Up until 2020, all of Bahrain's electricity generation was met by natural gas. The country plans to build a $100 \mathrm{MW}$ solar plant to be operational in 2021.

The Askar Solar Power Plant is a project under construction in the Askar area in the Southern Governorate in the Kingdom of Bahrain, according to a power purchase agreement (build, own, and operate). This project is considered the first photovoltaic power 
plant of this size in the Kingdom of Bahrain, where the project will generate 100 megawatts through solar energy, achieving nearly $50 \%$ of the target specified in the National Renewable Energy Action Plan in the Kingdom, which aims to reach the contribution of photovoltaic energy in the power mix to $255 \mathrm{MW}$ by 2025.

\subsection{Kuwait: Ambitious but Reluctant Developer}

Kuwait's government has set a target to increase the share of renewables in the energy mix to $10 \%$ by 2020 and $15 \%$ by 2030 . In Kuwait, the operational renewable energy projects presently consist of a handful of small demonstration projects. Launched in 2019, Shagaya Phase I is Kuwait's flagship renewable energy project [39]. Jointly developed by the Kuwait Institute for Scientific Research (KISR) and the Ministry of Electricity and Water, it consists of $10 \mathrm{MW}$ of solar PV capacity, $10 \mathrm{MW}$ of wind, and $50 \mathrm{MW}$ of CSP. The second phase of the project, Shagaya Phase II, is expected to be one of the largest solar projects in Kuwait, with a $1.5 \mathrm{GW}$ capacity. It is expected to generate $15 \%$ of the oil sector's electricity needs to the project's owner, the Kuwait National Petroleum Company.

The Shagaya Phase I project is managed by a consortium of the Spanish engineering company TSK and Kharafi National of Kuwait. While the Shagaya Phase I project is operational and feeds into the grid, there are still no regulations and policies in place for adopting renewable energy in the country.

Despite progress, there is still no dedicated entity to regulate and ensure that the country can achieve Kuwait's renewable energy targets. The current energy-related institutional landscape mainly supports the hydrocarbon sector. Supported by the Ministry of Oil, the Supreme Petroleum Council (SPC) oversees Kuwait's hydrocarbon sector policy. The Ministry for Electricity and Water, which also owns and operates Kuwait's electric power system, acts as the regulator of the electricity market. The entity that has been responsible for supporting the development of renewable energy is the Kuwait Institute for Scientific Research (KISR), which is an independent national institute that conducts scientific research and provides consulting services within Kuwait, the region and internationally. KISR has contributed to developing several renewable energy projects, including Kuwait's flagship solar PV, CSP and wind power project, Shagaya Phase I.

\subsection{Oman: Progressive Developer}

In Oman, the national oil company, the government, private, and academic sectors have been involved in developing few renewable energy projects. In 1995, the government established the first renewable energy project, a $10 \mathrm{~kW}$ wind-solar water desalination plant. Following the launch of its first study regarding the potential for Oman's renewable energy investments in 2008, the government approved the first renewable energy project in 2017, a $303 \mathrm{~kW}$ solar project in Al Mazyunah developed by the Rural Areas Electricity Company. Private investors have also launched their own pilot projects, including a $6 \mathrm{MW} \mathrm{CPV} \mathrm{solar}$ technology project built by a private investment company in 2010 and a $50 \mathrm{~kW}$ PV rooftop project developed by a state-owned electricity distribution company in 2012 [40]. Petroleum Development Oman (PDO; Oman's national oil company) has also been proactive in terms of studying the potential for renewable energy investment in Oman and in establishing its own pilot projects. In 2012, the PDO executed its first solar energy pilot project, a $7 \mathrm{MW}$ pilot project at Amal to test the commercial viability of solar steam producing 50 tons of steam a day for enhanced oil recovery [40].

Oman has adopted policies to support the adoption of renewable energy technologies both at a large scale and small scale. At the small scale level, for example, in 2013, the Authority for Public Services Regulation (formerly the Authority of Electricity Regulation) issued the first policy to incentivize the installation of renewable energy technologies in rural areas. Specifically, the new renewable energy policy aimed at integrating renewable energy into existing diesel-based energy systems that provide electricity to remote and rural areas. This policy drove the establishment of the first rural area pilot project Mazyonah 
$303 \mathrm{~kW}$ solar project. It also triggered the establishment of other rural area projects, such as the $500 \mathrm{~kW}$ wind-based pilot project based in the rural island of Masirah [40].

Furthermore, in 2017, Oman issued a policy that enables individuals, such as homeowners and industrial and commercial premises, to produce electricity from renewable energy sources like solar and sell the surplus to electricity distribution companies at the cost of electricity. This policy is locally called the 'Sahim' scheme. In the initial phase of Sahim, the homeowners were expected to pay for the installation of these cells, but in the second phase of Sahim, customers are not expected to bear the costs of procuring, installing, operating, or maintaining the systems. The distribution companies act as agents for the local single buyer of electricity and buy rooftop PV-generated electricity from consumers via a net metering mechanism that allows for compensation for electricity generated by rooftop PV panels [41].

On a large utility scale, in 2022, Oman inaugurated a 500 MW solar energy project in Ibri. The project is an Independent Power Plant awarded to the consortium led by the International Company for Water and Power Projects (ACWA Power) following an international competitive tender. Additionally, a $50 \mathrm{MW}$ wind farm project in south Oman became operation in 2019.

In Oman, the Authority for Public Services Regulation (formerly the Authority of Electricity Regulation) oversees the regulation of renewable energy development in the country, along with regulating electricity and water services. It is financially and administratively independent. The Authority reports directly to the Council of Ministers.

\subsection{Qatar: Ambitious but Stagnant Developer}

Qatar is the only Gulf country that has a factory that produces polysilicon, which is a key component in a range of solar photovoltaic (PV) technologies. Located in Ras Laffan Industrial City, $80 \mathrm{~km}$ north of Doha, Qatar Solar Technologies (QSTec) is a joint venture (JV) between Qatar Solar (a subsidiary of Qatar Foundation), Germany's SolarWorld AG, and Qatar Development Bank [42]. Furthermore, Qatar is the only Gulf country to have an operational waste-to-energy facility, the $30 \mathrm{MW}$ Mesaieed plant. While expected to be operational by the end of 2020, the first phase of the $800 \mathrm{MW} \mathrm{Al} \mathrm{Kharsaah} \mathrm{solar} \mathrm{PV}$ project reached financial close only late in 2020 [43]. Qatar's government set a target to meet $20 \%$ of its power demand from renewables by 2030 [42]. At present, however, Qatar is yet to have a dedicated entity that has clear mandates to support the development of renewable energy. Key institutions that have so far played a role in Qatar's renewable energy development include the Ministry of Energy and Industry, Qatar Electricity and Water Company (Kahramaa, the country's main utilities regulator), and the Qatar National Research Fund. The latter is a member of the Qatar Foundation and provides funds for research on a variety of subjects, including renewable energy.

\subsection{Saudi Arabia: Progressive Developer}

The Saudi National Renewable Energy Program plans to develop more than 35 projects across the Kingdom, which are being implemented by the Ministry of Energy.

The announced energy mix in the Kingdom of Saudi Arabia includes the goal of reaching $50 \%$ of renewable energy sources and $50 \%$ of gas by 2030 . The Kingdom's geographic location is among the best in the world for the production of solar and wind energy, and the Kingdom ranked sixth globally. It has the highest potential for solar energy production and ranked 13th in wind production on land [44]. The renewable energy capacity in Saudi Arabia reached 700 MW in 2021, with wind power representing 400 MW (Domat Al-Jandal project) at USD 0.199 per kilowatt-hour, and photovoltaic energy representing $300 \mathrm{MW}$ (Sakaka project), with the lowest supply ever for solar PV at a value of USD 0.234 per kilowatt-hour [45].

It is worth mentioning here that the Kingdom of Saudi Arabia, during its presidency of the G-20, proposed activating the Circular Carbon Economy Initiative (CCE), which was endorsed by all G-20 countries as an integrated and practical approach to managing emissions. 
The circular carbon economy also takes into account different national circumstances by including a wide range of pathways and options available. However, the main importance is the reduction of greenhouse gas emissions, considering the efficiency of the system, national conditions, including the resources identified for it, and the particular political, economic, environmental, and social development contexts. The circular carbon economy is based on the "three strategies" to protect the environment (mitigating, removing, reusing, and recycling). Moreover, it contributes to the realization of a fourth strategy, namely, removal, i.e., the attempt to eliminate accumulated emissions in the atmosphere.

\subsection{UAE: Leading Developer}

The UAE launched its National Energy Strategy 2050 in 2017, which aims to produce $50 \%$ of its energy needs from clean sources $(44 \%$ from renewable sources and $6 \%$ from nuclear sources) and reduce carbon emissions ("carbon footprint") by $70 \%$ by 2050 [46]. The UAE renewable energy capacity accounted for $68 \%$ of the total renewable energy capacity in the Gulf countries in 2018. The UAE has also played a leading regional role in the entry of the renewable energy sector to the Gulf countries, represented by hosting the headquarters of the International Renewable Energy Agency (IRENA).

Among the factors that helped the UAE expand the development of renewable energy early is its use of is utility-scale renewable energy auctions, which is the optimal policy framework to deploy renewable projects in a structured, cost-efficient, and generally transparent manner. Dubai's approach to renewable energy auctions provides a framework for very low PPAs. Since 2015, Dubai has established leadership in utility-scale solar PV auctions in which the PPA was signed for Dubai's first renewable energy IPP at the Mohammad bin Rashid Al Maktoum (MBR) Solar Park. Long-term, the PPA has a 25-year second phase solar park development, as well as a role in the local electricity authority. The Dubai Water and Electricity Authority (DEWA) is taking part ownership (51\%) in the project consortium that won the bid, and being the electricity off-taker from a governmentestablished site are complementary factors to the success of auctioned projects [47].

The establishment of the MBR Solar Park is one very important factor for the successful promotion of renewable energy in Dubai because designated government locations create certainty for investors regarding the availability of solar resources as well as necessary grid connections. Another factor for Dubai's success is attractive financing. The low PPA prices were achieved by extremely attractive financing terms offered by UAE banks with debt financing at $86 \%$ of the total project value with an interest rate near $4 \%$ and a 27 -year tenor. Furthermore, minimal, if any, costs for land and grid connections and forward projections on improved technology performance were other factors in Dubai.

\section{Why Is the Share of Renewables Still Low in the GCC?}

Despite progress in deploying renewables across the GCC, there are many challenges in their development. Acknowledging the significance of these challenges differ from one country to another, these can be classified into institutional, market-related, technical, and cultural.

\subsection{Institutional Barriers: Evolving but Limited Institutional Capacity to Support Renewable Energy}

The institutional barriers that had impeded the deployment of renewable energy in the GCC are: (i) approval process to obtain long-term licensing; (ii) inconsistent national energy policy; and (iii) limited experience with renewables and know-how among officials (Figure 2).

A main institutional barrier had been (i) approval process to obtain long-term licensing, permitting, and approval to authorize installation of renewable energy projects. Each of these processes requires consultation, review, and approval from multiple agencies and levels of government with little to no streamlining. One factor that has contributed to elongating the approval process to get licensing or permits is complicated governance 
processes. The complicated governance processes have been a result of the existence of multiple agencies to oversee the implementation of renewable energy projects. Importantly, inadequate coordination between these entities and, in some cases, the lack of a renewable energy-dedicated entity has had major issues to complicate governance processes and the subsequent long-term approval process. Moreover, limited cooperation between different government entities or government and business and academic entities has been a barrier delaying the deployment of renewable energy in some GCC states [48]. Another factor that contributes to elongating the approval process is the limitations in the design and implementation of renewable regulatory frameworks $[11,12,15,16]$. While all GCC states have set targets to increase the share of renewable energy in their energy mix profile, regulatory frameworks that facilitate and incentivize the deployment of renewables are mostly lacking or need to be strengthened. Renewable energy does not receive enough legislative and regulatory support compared to conventional modes of power generation. In some cases, the power sector law, which dominantly supports the conventional modes of power generation, includes less (or lack thereof) regulatory and institutional backing or elements that support the deployment of renewable energy [48].

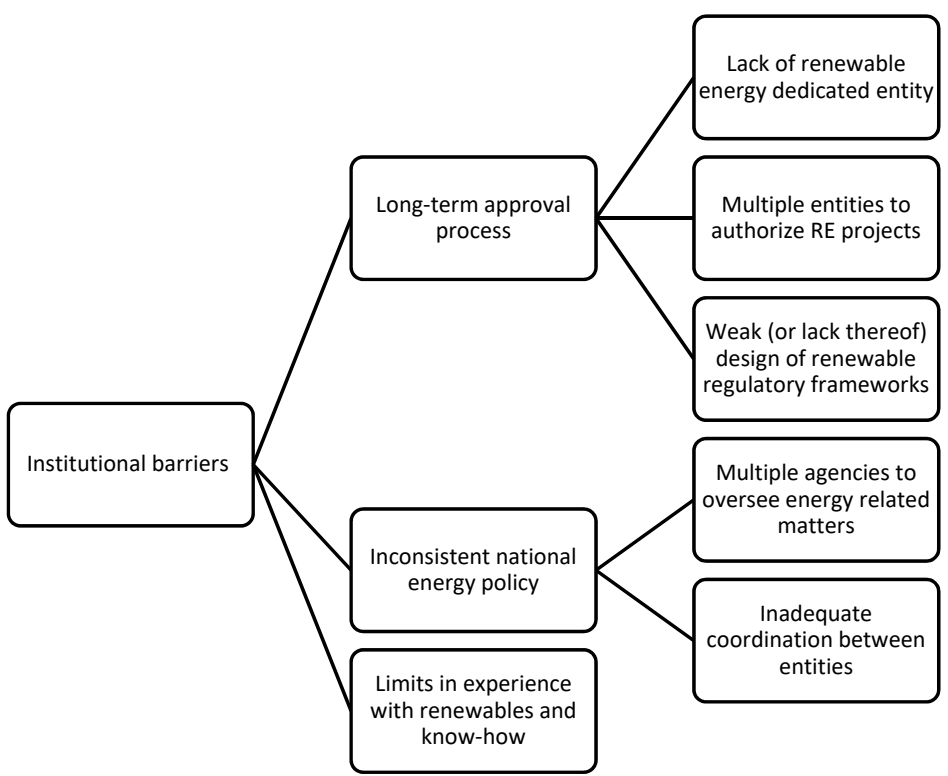

Figure 2. Institutional barriers for renewable energy adoption in the GCC. Adapted from [48].

A second institutional barrier is (ii) an inconsistent national energy policy due to the existence of multiple agencies, which has led to viewing energy-related matters-such as oil, gas, electricity, water desalination, greenhouse gas emission reduction, and renewable energy-separately [16,48]. This might be explained by the persistence of hierarchal, topdown governmental decision-making and, in some cases, the under-representation of renewable energy interest groups in the high-level decision-making arena, leaving little room for influencing or contributing to changes in state laws.

A third institutional barrier had been (iii) limits in experience with renewables and know-how among officials leading to delays in governmental initiation of new policies, strategies, and project approvals $[11,15,48,49]$. This also explains the delayed governmental reaction to international environmental agreements, approving new renewable energy targets, or making changes to existing laws.

\subsection{Market Barriers: Favoritism towards Conventional Electricity Sources over Renewables}

Two major market barriers impede the deployment of renewable energy in the GCC: (i) economic barriers, which disadvantage the competitiveness of renewable energy technologies, and (ii) high investment uncertainties (Figure 3). 


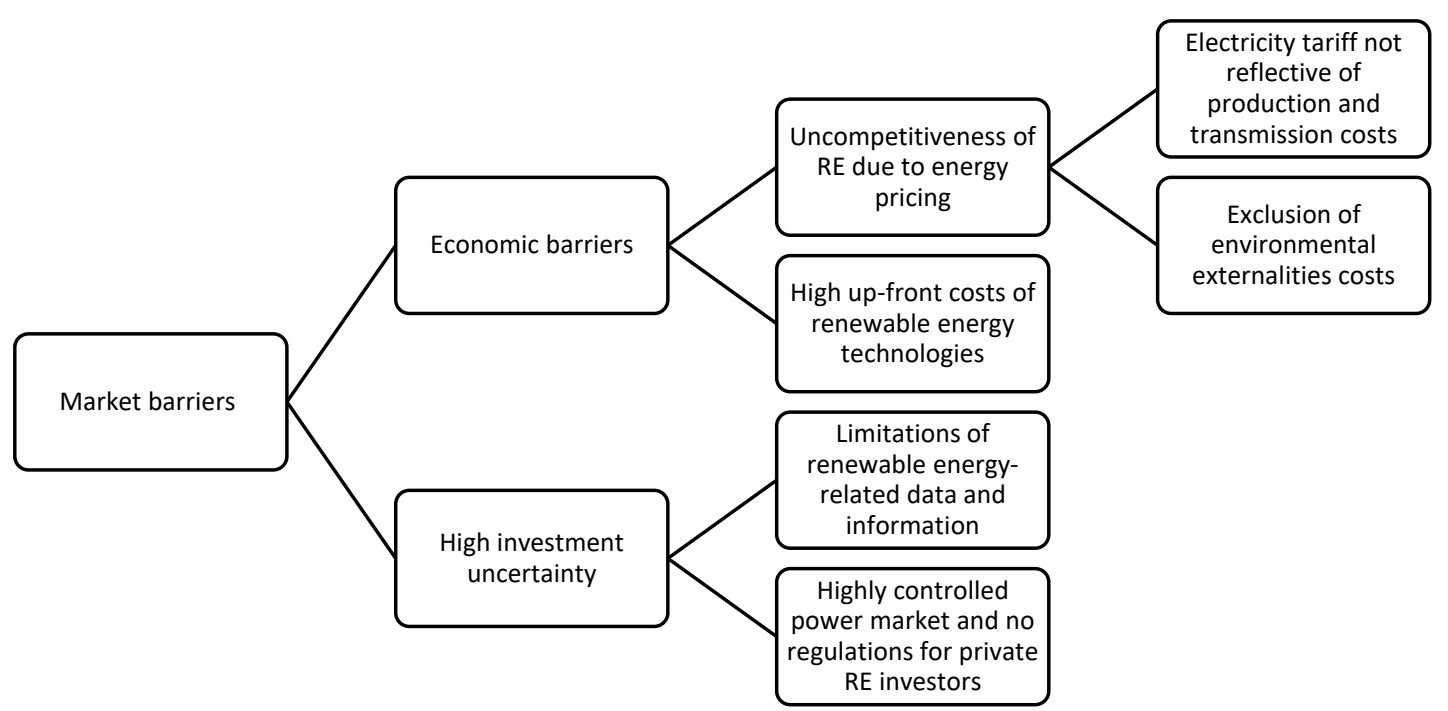

Figure 3. Market barriers for renewable energy adoption in the GCC. Adapted from [48].

Regarding economic barriers, the governmental energy pricing in the form of subsidies on gas, diesel, and electricity tariffs along with the exclusion of the costs of environmental externalities, are major barriers to eliminate the competitiveness of renewable energy technologies, and hence their limited penetration into GCC's electricity market [11].

Furthermore, high up-front costs of renewable energy technologies and long payback periods have been barriers that disadvantage the competitiveness of renewable energy technologies with conventional energy sources $[11,15,19,21]$. This has been highly advantaged by the current sector's law that specifies technology, economic, and technical conditions in favor of oil and gas-based technologies. The upfront costs remain to be seen, partially due to the exclusion of environmental externalities in evaluating the cost of fuels-namely oil and gas-and due to the lack of subsidy mechanisms that support the development of renewable energy technologies [11].

In addition to the economic barriers, the second market barrier was (ii) high investment uncertainty, which was reinforced by the limitation of available renewable energy-related data and information and a highly controlled market [16,48]. Limitation of available data and information regarding renewable energy resource availability is a challenge for investors wishing to access the necessary information needed for investment decisions. The limitation of available data and information has also been a challenge for decision makers at the government level because decision-making processes need to be guided by adequate information. This limitation explains the reasons behind delays in the approval of renewable energy projects. On the other hand, the highly controlled power market, wherein most of the power sector's value chain companies are owned by the government, challenged the entry of renewable energy private investors, especially small and medium enterprises who are not advantaged by the state patronage [48]. Given the decentralized nature of renewables, small and medium enterprises, in many cases, cannot generate power on a large scale as in open-cycle gas turbines (OCGT) or closed-cycle gas turbines (CCGT). Therefore, small and medium enterprises can be locked in by the highly controlled power market, which, at the generation side, favors large scale power generation facilities and, at the distribution side, restricts the distribution of electricity to licensed state-owned distribution companies that can only purchase their electricity from the single buyer and seller of electricity.

\subsection{Technical Barriers: Unfamiliarity with New Technical Challenges Associated with Renewables}

Four main technical barriers have been impeding the deployment of renewable energy in the GCC: (i) the confidence in new technology; (ii) access to the national grid; (iii) the 
availability of areas required to install renewable energy technologies; and (iv) availability of skilled workforce (Figure 4).

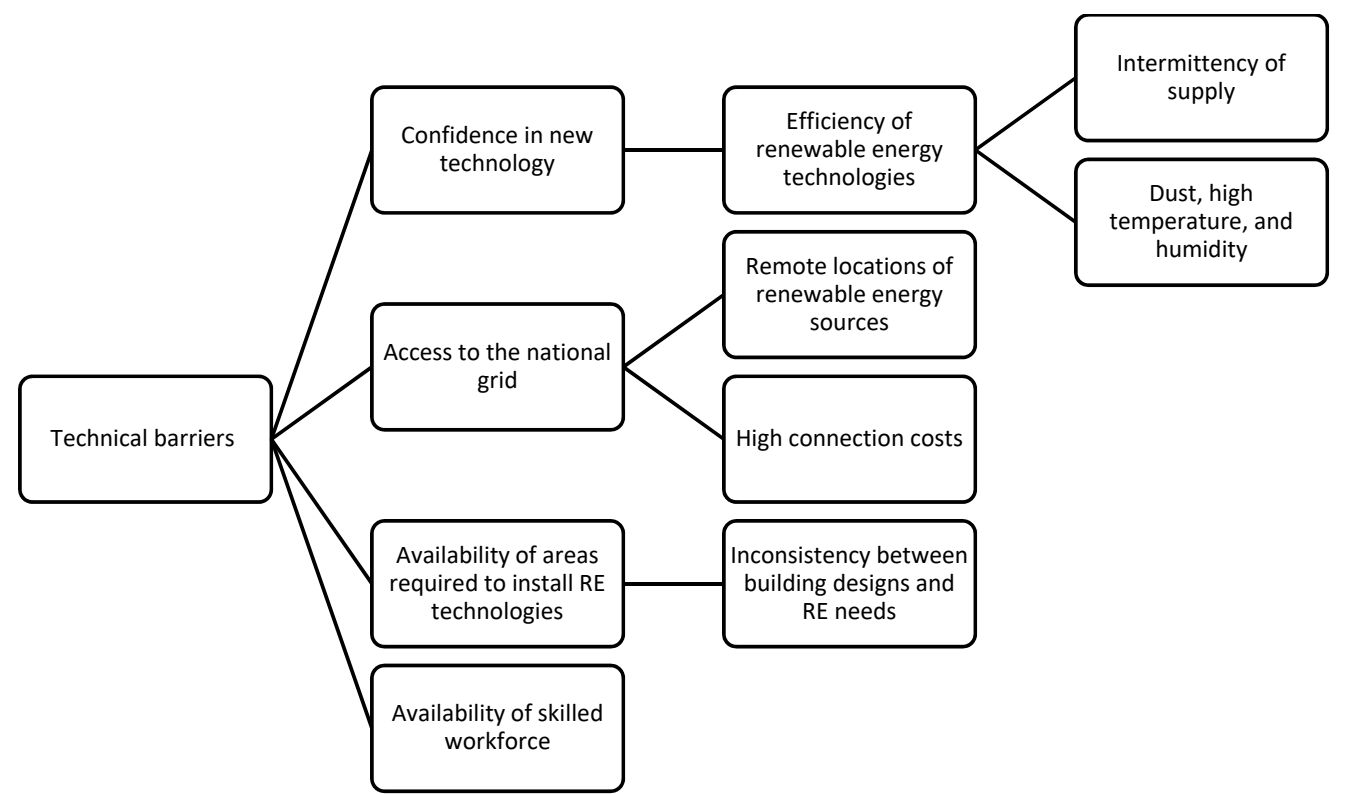

Figure 4. Technical barriers for renewable energy adoption in the GCC. Adapted from [48].

The main technical barrier has been the confidence in new technology. That is due to the low technological efficiency of renewable energy technologies compared to existing sources of power such as OCGT or CCGT, which have already achieved economy of scale [48]. Specifically, RE technical efficiency is reduced by the specific environmental conditions of the GCC. According to current practices, the efficiency of renewable energy technologies (especially PV modules) in the GCC is faced with challenging existing environmental conditions, including dust, high temperature, and humidity. It is estimated that, for instance, Oman's arid environmental conditions may reduce the efficiency of PV cells by approximately 10\% compared with standard conditions [15,50]. Furthermore, unpredictability and intermittent supply of renewable energy sources is another technical challenge to the development of renewable energy technologies [11]. Given that the peak production of energy from renewable energy resources coincides with peak energy demands, such as midday during summer times (due to the use of air conditioners), a need for energy storage may not be significant during the peak hours, yet is as an issue to meet energy needs during off-peak hours.

Furthermore, (ii) access to the national grid has been another technical barrier. All GCC countries allow for third-party access to the electricity grid through the dedicated power agency that authorizes grid connection licenses [51]. However, most identified renewable energy resources in the GCC, especially wind and solar, are available in remote locations away from the main national grid or the main sites of power demand, such as coastal zones. That is, enabling grid access to remote locations might incur high connection costs, energy losses due to the long distances, and indeed would require grid code upgrades $[15,16,48]$.

In addition, (iii) the availability of area required to install renewable energy technologies presents a mix of challenges and opportunities for RE adoption in the GCC. The inconsistency between present infrastructure planning (such as rooftop design) and the specific needs of new technologies installation (like renewables) disadvantaged the installation of renewable energy technologies [48]. However, with the exception of Kuwait and Bahrain [12], the availability of areas to install large-scale renewable energy projects such as CSP is an advantage in the GCC because there are vast areas that do not need to be altered for any future installations (e.g., flat deserts) $[7,11,17]$. 
Finally, (iv) the limited skilled workforce to maintain and operate renewable energy technologies is another technical challenge that needs to be addressed to support renewable energy deployment in the GCC.

\subsection{Cultural Barriers: Lack of Incentives and Desire for Renewable Energy}

Public acceptance of renewable energy technologies, especially small-scale renewable energy systems, will remain a challenge, as nearly $100 \%$ of GCC nationals have access to electricity that is provided at low costs due to significant government support for this sector [51]. Easy access to electricity at historically low costs has contributed to a number of negative cultural behaviors, such as excessive energy consumption, which impedes motivating residents to switch to renewable energy sources. Renewables are an expensive option compared to accessible cheap conventional energy supplies. This, in turn, eliminates the demand for renewable energy technologies, which in turn leads to a decrease in demand for renewable energy products [51]. This easy access to cheap electricity may be another reason to distract customer awareness from the advantages of renewable energy technologies [28,52] (Figure 5).

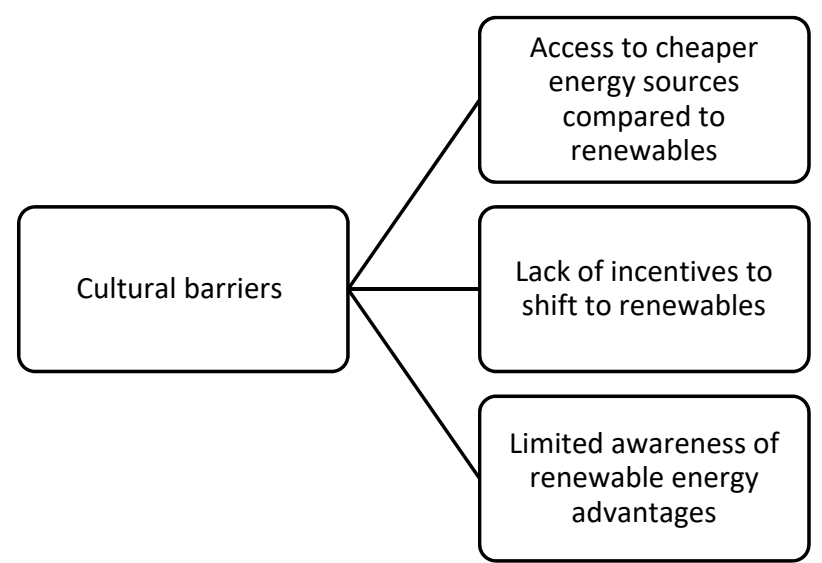

Figure 5. Cultural barriers for renewable energy adoption in the GCC. Adapted from [48].

\subsection{Innovation and Domestic Technological Production: Rising RED Efforts but Further Support Needed}

Despite the growth in the employment of renewable energy in the past few years, the Gulf countries, with the exception of Qatar and Saudi Arabia, are not competitive in the field of innovation and the production of renewable energy technology and rely heavily on importing the necessary technology and expertise from abroad.

There is an increasing growth in research and development support to enhance sustainable energy technologies and adapt them to the market and local climatic conditions. Examples include the Masdar Institute in the UAE and the Qatar Environment and Energy Research Institute. However, the Gulf countries still need a strong infrastructure to support and encourage innovation at the local level [11]. In 2020, the average ratio of investment in research and development to GDP in the Gulf countries was 0.2\% in Oman, $0.1 \%$ in Bahrain, $0.8 \%$ in Saudi Arabia, $0.5 \%$ in Qatar, and $0.8 \%$ in Qatar, $4 \%$ in Kuwait, and $0.7 \%$ in the United Arab Emirates, compared to 2\% to 3\% in industrialized countries. Gulf countries' investments in research and development are well below the minimum percentage $(1 \%)$ needed for an effective science and technology base as set by UNESCO [53].

It should be noted here that many large companies, if not the majority of them, do not have in-house R\&D departments, but the direction of new technologies is mainly through joint venture arrangements with foreign partners who lead the project in technology. Furthermore, most R\&D institutions serve the interests of the company itself, which leaves little room for stimulating innovation in collaboration with smaller companies, R\&D entities, 
or academia. There is also a strong preference for technology imports through international trade, and this applies to renewable energy technologies as well [54].

\section{Conclusions and Policy Insights}

The aim of this study was to diagnose the current state of renewable energy development in the GCC and to identify the factors that have slowed down the adoption of renewable energy in the hydrocarbon-rich GCC states.

The GCC countries have shown progressive governmental support to renewable energy development and deployment over the last decade. Yet, the contribution of renewable energy in meeting the needs of energy provisions remains significantly small compared to the hydrocarbon resources, namely oil and gas, due to decades of abundance and experience with hydrocarbon resources. Whereas technical and economic feasibility issues have been identified as the main barriers to slowing the uptake of RE in the GCC, this paper uncovered that numerous additional factors have notably influenced such delays. These include institutional barriers, especially due to fragmented energy policy, the lack of or weakness of dedicated renewable energy entity, and a dedicated renewable energy regulatory framework. Unless receiving a proper governmental intervention, market barriers also exist to play a role in reducing the competitiveness of renewable energy technologies in the GCC because of high hydrocarbon subsidies, low electricity tariff structure, and highly controlled power market. Furthermore, while the support of renewable energy development in the GCC has received enormous attention and effort from local research entities, the implications of research outcomes do not span beyond the research arena, and the coordination gap between research, government, and the private sector remains wide. To overcome these challenges, we suggest:

\subsection{Establish Dedicated Entity with Clear Mandates to Support Meeting Renewable Energy Targets}

While all the Gulf Arab countries have announced ambitious goals with regard to renewable energy, some of these countries do not yet have a dedicated entity with clear powers and dedicated renewable energy regulatory frameworks to oversee the deployment of renewable energy sources and the achievement of the specified goals. Establishing a dedicated entity with clear terms of reference will reduce the institutional barriers mentioned in this paper, including facilitating the process of governance and obtaining the necessary permits and approvals for the development of renewable energy projects. It will also contribute to enhancing coordination of efforts for energy-related issues such as oil, gas, electricity, water desalination, reducing greenhouse gas emissions, and renewable energy among various energy entities.

\subsection{Ensure Coordination between Different Energy Entities to Ensure Consistency and Avoid Policy Fragmentation}

The collective action of all actors involved in renewable energy development-including public, private, financial, and academic - is essential to enabling a systematic transition towards renewable energy. The early recognition of the importance of each actor's involvement in the decision-making process will minimize the risks associated with the uptake of renewable energy technologies and would enable the deployment of renewables on a large scale. Additionally, the involvement of different actors will help in avoiding the duplication of efforts and conflicts of interest, while ensuring effective coordination of efforts. It will also facilitate the sharing of knowledge, lessons, and experiences, as well as the flow of resources between actors.

\subsection{Energy Subsidies}

Review the pricing of hydrocarbons so that electricity prices reflect the cost of production. This will not only increase the competitiveness of renewable energy sources and promote efficient use of energy but will also reduce pressure on the budget of the Gulf states. However, attention should be paid to reviewing hydrocarbon prices and taking into account 
the potential effects of eliminating these subsidies on low-income consumers, especially in the residential sector. We find that the UAE, Bahrain, Saudi Arabia, and the Sultanate of Oman are the Gulf countries that have reformed their hydrocarbon subsidies among the GCC countries, bearing in mind the potential impact on low- and middle-income people.

\subsection{Financial Incentives}

Dedicated financial instruments are needed in order to incentivize investors to engage in renewable energy development, especially small private investors. Direct cash grants or soft loans can be a policy method of reducing the high upfront investment costs of renewables. Subsidies to support medium- to large-scale renewable energy asset investments can be an attractive mechanism for creating competitive environments for renewable energy projects and conventional energy supply technologies.

\subsection{Support Distributional Renewables Alongside Large-Scale Projects}

Rooftop PV module installations (solar panels) can be promising for the spread of small-scale renewable energy projects. Net metering-a billing mechanism that credits solar energy system owners for the electricity they generate-also has the potential to encourage consumers to measure their own electricity consumption and production from renewable sources. An additional point regarding enhancing the demand for renewables is the need to promote public awareness of the new RE technologies.

\subsection{Support Investment in Research and Development and Work to Provide a Strong Infrastructure to Encourage Innovation at the National Level}

The Gulf countries should focus on providing financial support for the development of renewable energy technology at the local level in order to reduce dependence on other countries to import renewable energy technology, especially that most of the imported renewable energy technologies do not work efficiently in the environment of the Gulf countries, due to several factors such as humidity, heat, and dust. Most importantly, the institutional structure needed to support innovation and stimulate cooperation between all stakeholders, including the academic, private, and government sectors, must be strengthened.

While secondary data and information are useful to inform the understanding of general and specific barriers that have impeded the deployment of renewable energy in the GCC, it is worth noting that this paper can benefit from an in-depth case study investigation to understand country-specific barriers and developments. Therefore, primary data collection through semi-structured interviews with stakeholders from academia, government, and the private sector would help to give an in-depth understanding of renewable energy development and barriers in each of the six GCC states.

Author Contributions: Conceptualization, A.A.-S.; investigation, A.A.-S.; resources, A.A.-S. and N.M.; data curation, A.A.-S.; writing-original draft preparation, A.A.-S.; writing-review and editing by all authors. All authors have read and agreed to the published version of the manuscript.

Funding: This research received no external funding.

Institutional Review Board Statement: Not applicable.

Informed Consent Statement: Not applicable.

Data Availability Statement: Not applicable.

Acknowledgments: The authors would like to thank colleagues for their time and effort to review initial drafts of this paper: Salaheddine Soummane (KAPSARC), Amro Elshurafa (KAPSARC), Mohamad Hejazi (KAPSARC), Fahad Alturki (KAPSARC), Omar Al-Shehabi (Gulf Centre for Development Studies), and Rawan Maki (London College of Fashion).

Conflicts of Interest: The authors declare no conflict of interest. 


\section{References}

1. Stocker, T.F.; Qin, D.; Plattner, G.-K.; Tignor, M.; Allen, S.K.; Boschung, J.A.; Nauels, Y.; Xia, V.B.; Midgley, P.M. (Eds.) IPCC, 2013: Climate Change 2013: The Physical Science Basis, Contribution of Working Group I to the Fifth Assessment Report of the Intergovernmental Panel on Climate Change; Cambridge University Press: Cambridge, UK; New York, NY, USA, 2013; p. 1535.

2. Masson-Delmotte, V.; Zhai, P.; Pirani, A.; Connors, S.L.; Péan, C.; Berger, S.; Caud, N.; Chen, Y.; Goldfarb, L.; Gomis, M.I.; et al. (Eds.) IPCC, 2021: Climate Change 2021: The Physical Science Basis, Contribution of Working Group I to the Sixth Assessment Report of the Intergovernmental Panel on Climate Change; Cambridge University Press: Cambridge, UK, 2021; in press.

3. Bp. Statistical Review of World Energy_Full Report-BP Statistical Review of World Energy; 69th ed.; 2020. Available online: https://www.bp.com/content/dam/bp/business-sites/en/global/corporate/pdfs/energy-economics/statistical-review / bp-stats-review-2020-full-report.pdf (accessed on 20 January 2022).

4. World Resource Institute. Climate Watch (CAIT): Country Greenhouse Gas Emissions Data. 2020. Available online: https: / / www.wri.org/data/climate-watch-cait-country-greenhouse-gas-emissions-data (accessed on 1 February 2022).

5. Jalilvand, D.R. Renewable Energy for the Middle East and North Africa Policies for a Successful Transition; Fredric Ebert Stiftung: Bonn, Germany, 2012.

6. Alnaser, W.E.; Alnaser, N.W. Solar and wind energy potential in GCC countries and some related projects. J. Renew. Sustain. Energy 2009, 1, 022301. [CrossRef]

7. IRENA. Renewable Energy Market Analysis: GCC 2019; International Renewable Energy Agency (IRENA): Abu Dhabi, United Arab Emirates, 2019.

8. Bp. bp Statistical Review of World Energy 2021, 70th ed. Available online: https://www.bp.com/content/dam/bp/businesssites/en/global/corporate/pdfs/energy-economics/statistical-review/bp-stats-review-2021-full-report.pdf (accessed on 1 February 2022).

9. IRENA. Renewable Capacity Statistics 2021; International Renewable Energy Agency (IRENA): Abu Dhabi, United Arab Emirates, 2021.

10. Alnaser, W.; Alnaser, N. The status of renewable energy in the GCC countries. Renew. Sustain. Energy Rev. 2011, 15, 3074-3098. [CrossRef]

11. Ferroukhi, R.; Ghazal-Aswad, N.; Androulaki, S.; Hawila, D.; Mezher, T. Renewable energy in the GCC: Status and challenges. Int. J. Energy Sect. Manag. 2013, 7, 84-112. [CrossRef]

12. Elrahmani, A.; Hannun, J.; Eljack, F.; Kazi, M.-K. Status of renewable energy in the GCC region and future opportunities. Curr. Opin. Chem. Eng. 2020, 31, 100664. [CrossRef]

13. El-Katiri, L. A Roadmap for Renewable Energy in the Middle East and North Africa; Oxford Institute for Energy Studies: Oxford, UK, 2014. [CrossRef]

14. El-Katiri, L.; Husain, M. Prospects for Renewable Energy in GCC States; Oxford Institute for Energy Studies: Oxford, UK, 2014. [CrossRef]

15. Munawwar, S.; Ghedira, H. A review of Renewable Energy and Solar Industry Growth in the GCC Region. Energy Procedia 2014, 57, 3191-3202. [CrossRef]

16. Abdmouleh, Z.; Alammari, R.A.; Gastli, A. Recommendations on renewable energy policies for the GCC countries. Renew. Sustain. Energy Rev. 2015, 50, 1181-1191. [CrossRef]

17. Mondal, A.H.; Hawila, D.; Kennedy, S.; Mezher, T. The GCC countries RE-readiness: Strengths and gaps for development of renewable energy technologies. Renew. Sustain. Energy Rev. 2016, 54, 1114-1128. [CrossRef]

18. Salim, A.; Alsyouf, I. Development of renewable energy in the GCC region: Status and challenges. Int. J. Energy Sect. Manag. 2020, 14, 1049-1071. [CrossRef]

19. Connelly, C.; Xydis, G. Wind energy in the Gulf Cooperation Council region: Progress, challenges and strategies for development. Rev. Econ. Polit. Sci. 2021, 6, 287-291. [CrossRef]

20. Krupa, J.; Poudineh, R.; Harvey, L.D. Renewable electricity finance in the resource-rich countries of the Middle East and North Africa: A case study on the Gulf Cooperation Council. Energy 2018, 166, 1047-1062. [CrossRef]

21. World Bank. Fuel Exports (\% of Merchandise Exports). 2020. Available online: https://data.worldbank.org/indicator/TX.VAL. FUEL.ZS.UN (accessed on 8 December 2020).

22. World Bank. Oil Rents (\% of GDP). 2020. Available online: https:/ / data.worldbank.org/indicator/NY.GDP.PETR.RT.ZS (accessed on 8 December 2020).

23. IRENA. Global Renewables Outlook: Energy Transformation 2050; International Renewable Energy Agency: Abu Dhabi, United Arab Emirates, 2020.

24. Garrett-Peltier, H. Green versus brown: Comparing the employment impacts of energy efficiency, renewable energy, and fossil fuels using an input-output model. Econ. Model. 2017, 61, 439-447. [CrossRef]

25. Jacobson, M.Z.; Delucchi, M.A.; Cameron, M.A.; Coughlin, S.J.; Hay, C.A.; Manogaran, I.P.; Shu, Y.; von Krauland, A.-K. Impacts of Green New Deal Energy Plans on Grid Stability, Costs, Jobs, Health, and Climate in 143 Countries. One Earth 2019, 1, 449-463. [CrossRef]

26. IQAir. World's Most Polluted Countries 2019 (PM2.5). World Air Quality Index. 2019. Available online: https://www.iqair.com/ world-most-polluted-countries (accessed on 27 December 2020). 
27. Omri, A.; Belaïd, F. Does renewable energy modulate the negative effect of environmental issues on the socio-economic welfare? J. Environ. Manag. 2020, 278, 111483. [CrossRef] [PubMed]

28. Praveen, R.; Keloth, V.; Abo-Khalil, A.G.; Alghamdi, A.S.; Eltamaly, A.M.; Tlili, I. An insight to the energy policy of GCC countries to meet renewable energy targets of 2030. Energy Policy 2020, 147, 111864. [CrossRef]

29. International Energy Agency. IEA Atlas of Energy. Energy Balance. Available online: http://energyatlas.iea.org/\#!/tellmap/-100 2896040/1 (accessed on 13 October 2019).

30. El-Katiri, L. Energy Sustainability in the Gulf States-The Why and the How; Oxford Institute for Energy Studies: Oxford, UK, 2013

31. Kompas, T.; Pham, V.H.; Che, T.N. The Effects of Climate Change on GDP by Country and the Global Economic Gains from Complying with the Paris Climate Accord. Earth's Future 2018, 6, 1153-1173. [CrossRef]

32. IEA. Outlook for Producer Economies 2018: What do Changing Energy Dynamics Mean for Major Oil and Gas Exporters? International Energy Agency: Paris, France, 2018.

33. Manley, D.; Cust, J.; Cecchinato, G. Stranded Nations? The Climate Policy Implications for Fossil Fuel-Rich Developing Countries; Working Paper 34; Oxford Centre for the Analysis of Resource Rich Economies, University of Oxford: Oxford, UK, 2017.

34. Al-Sarihi, A. Prospects for Climate Change Integration in GCC Economic Diversification Strategies; LSE Middle East Centre Working Paper 20; Kuwait Programme; LSE Middle East Centre: London, UK, 2018.

35. Luomi, M. Gulf States' Climate Change Policies Amid a Global Pandemic; Issue paper No. 6; The Arab Gulf States Institute in Washington: Washington, DC, USA, 2020.

36. Kingdom of Saudi Arabia. Updated First Nationally Determined Contribution. 2021 Submission to the UNFCCC. October 25 2021. Available online: https://www4.unfccc.int/sites/ndcstaging/PublishedDocuments/Saudi\%20Arabia\%20First/KSA\% 20NDC\%202021\%20FINAL\%20v24\%20Submitted\%20to\%20UNFCCC.pdf. (accessed on 1 February 2022).

37. Sultanate of Oman, Civil Aviation Authority. Second Nationally Determined Contribution; Date submitted to the UNFCCC: 29 July 2021; Sultanate of Oman: Muscat, Oman, 2021.

38. Analyzing the impact of Bapco 5 MW Solar PV Grid-Connected Project on Bahrain's Outlook for Energy-Mix Production. Int. J. Mod. Nonlinear Theory Appl. 2019, 8, 72-91. [CrossRef]

39. KISR. Shagaya Concentrated Solar Power Project. Kuwait Institute for Scientific Research (KISR), Kuwait. 2020. Available online: https:/ / www.kisr.edu.kw/en/gi/5/details / (accessed on 20 December 2020).

40. Al-Sarihi, A.; Cherni, J.A. Assessing strengths and weaknesses of renewable energy initiatives in Oman: An analysis with strategic niche management. Energy Transit. 2018, 2, 15-29. [CrossRef]

41. Viswanathan, G. "Sahim" Scheme to Power Homes by Solar Energy, Times of Oman. Available online: http://timesofoman.com/ article/109724/Oman/Solar-energy-initiative- \T1 \textquoterightSahim $\backslash \mathrm{T} 1 \backslash$ textquoteright-launched-in-Oman (accessed on 20 December 2020).

42. Oxford Business Group. Qatar Gets Serious About Solar. 2017. Available online: https:/ / oxfordbusinessgroup.com/news/qatargets-serious-about-solar (accessed on 20 December 2020).

43. Thompson, M. Al Kharsaah: How Low Can Solar Tariff Bids go? TXF. 2020. Available online: https://www.txfnews.com/News/ Article/7038/Al-Kharsaah-How-low-can-solar-tariff-bids-go (accessed on 20 December 2020).

44. AlGhamdi, A. Saudi Arabia Energy Report 2020; King Abdullah Petroleum Studies and Research Center: Riyadh, Saudi Arabia, 2020.

45. ACWA Power. Acwa Power Wins the First Ever Utility Scale Renewable Energy Project in Saudi Arabia. 2018. Available online: https: / / www.acwapower.com/news/acwa-power-wins-the-first-ever-utility-scale-renewable-energy-project-in-saudiarabia/ (accessed on 20 December 2020).

46. UAE Government portal. UAE Energy Strategy 2050. The United Arab Emirates. Available online: https://u.ae/en/about-theuae/strategies-initiatives-and-awards / federal-governments-strategies-and-plans/uae-energy-strategy-2050 (accessed on 20 December 2020).

47. Griffiths, S. Renewable energy policy trends and recommendations for GCC countries. Energy Transit. 2017, 1, 3. [CrossRef]

48. Al-Sarihi, A. A Study of the Challenges and Opportunities to Adopting Renewable Energy in Oman. Ph.D. Thesis, Imperial College London: London, UK, 2018. [CrossRef]

49. Al Hatmi, Y.; Tan, C.S.; Al Badi, A.; Charabi, Y. Assessment of the consciousness levels on renewable energy re-sources in the Sultanate of Oman. Renew. Sustain. Energy Rev. 2014, 40, 1081-1089. [CrossRef]

50. Charabi, Y.; Gastli, A. Integration of temperature and dust effects in siting large PV power plant in hot arid area. Renew. Energy 2013, 57, 635-644. [CrossRef]

51. Dustegor, D.; Sultana, N.; Felemban, N.; Al-Qahtani, D. Public acceptance of renewable energy and Smart-Grid in Saudi Arabia. In Proceedings of the 8th GCC Conference \& Exhibition, Muscat, Oman, 1-4 February 2015; pp. 1-6. [CrossRef]

52. Taleb, H.M.; Pitts, A.C. The potential to exploit use of building-integrated photovoltaics in countries of the Gulf Cooperation Council. Renew. Energy 2009, 34, 1092-1099. [CrossRef]

53. UNESCO Institute for Statistics. How Much Does Your Country Spend in R\&D? Available online: http://uis.unesco.org/apps/ visualisations/research-and-development-spending/ (accessed on 14 June 2021).

54. Al-Sarihi, A. What's Keeping GCC States from Unlocking Their Innovation Potential? Middle East Institute: Singapore; National University of Singapore: Singapore, 2021. Available online: https://mei.nus.edu.sg/think_in/whats-keeping-gcc-states-fromunlocking-their-innovation-potential/ (accessed on 30 January 2022). 